\title{
Using Geochemical and Environmental Isotopes Composition to Study the Possible Leakage between Two Major Aquifers, Eastern Saudi Arabia
}

\author{
Mahmoud S. Alyamani and Mohammed A. Sharaf \\ Faculty of Earth Sciences, King Abdulaziz University \\ P.O. Box 80206, Jeddah 21589, Saudi Arabia
}

Received: 27/11/2004 Revised: 22/2/2005 Accepted: 26/2/2005

\begin{abstract}
Major ion analyses of 156 fresh and mineral groundwater samples from Umm Er Radhuma aquifer (UER) in eastern part of Saudi Arabia reveal a consistent pattern of variation in the sedimentary basin. The piezometric data shows a broad pattern of regional flow from west to east towards the Arabian Gulf coast. The groundwater chemistry is highly variable, where TDS ranged between 220 and $15815 \mathrm{mg} / \mathrm{l}$; with an average of about $2257 \mathrm{mg} / \mathrm{l}$. The chemical and isotopical compositions of the groundwater of UER aquifer show that the water is progressively enriched in $\mathrm{Na}^{+}, \mathrm{Ca}^{2+}, \mathrm{Mg}^{2+}, \mathrm{Cl}^{-}$and $\mathrm{SO}_{4}^{2-}$ while isotopically $\left(\delta^{18} \mathrm{O}\right.$ and $\left.\delta \mathrm{D}\right)$ depleted in the direction of flow. The isotopic contents of the groundwater of UER, measurements of the piezometric level and stratification of groundwater chemistry with depth suggest that the UER aquifer receives a considerable amount of water leaking from the overlying Dammam Formation characterized by being younger and low in TDS. The groundwater chemistry in UER aquifer, therefore, is mainly controlled by mixing processes besides, the chemical reactions that take place between water and aquifer materials within the UER aquifer through its movement.
\end{abstract}

KEYwords: Groundwater chemistry, Leakage process, Sedimentary ba$\sin$.

\section{Introduction}

The Umm Er Radhuma (UER) formation lies within latitude $28^{\circ} 41^{\prime} \mathrm{N}$ and longitude $44^{\circ} 41^{\prime} \mathrm{E}$ in the eastern province of Saudi Arabia (Fig. 1). It covers a surface area of about $160,000 \mathrm{~km}^{2}$. Hydrogeologically and hydrochemically, the 
aquifer has been studied intensively since early 1970's (e.g. Watuki, 1968 and 1971; Sogreah, 1968; Italoconsult, 1969; Groundwater Development Consultant Company (GDC), 1979; BRGM, 1976 and 1979; Al-Sayari and Zotl, 1978; AlBassam, 1983, and 1987; Sharaf, 2001). It is considered a major groundwater reservoir of the Arabian Peninsula. Throughout the study area, the groundwater chemistry is highly variable. The available data concerning the chemical and isotopical composition of the groundwater indicated that an anomalous pattern existed. It shows that the groundwater down gradient becomes progressively enriched in major constituents, while its isotopic content is being depleted. Normally, it would be expected that the isotopic composition often followed similar trend that was observed in the chemical composition and to be enriched with heavy isotopes. The existence of this variation led us to investigate the groundwater conditions and define factor(s) that affect its observed chemistry and isotopic contents. The data concerning the hydrogeological and hydrochemical characteristics used by Sharaf (2001) was adopted in the present investigation.

\section{Geology and Hydrogeology}

The rock types, formed in a shallow sea, consist of a series of light colored, dense limestones, dolomitic limestones, and dolomite. Marl and shale are also found in the upper part of the formation in the central and southern areas. In the north, significant layers of anhydrite and some chert are found in the upper part. The stratigraphic succession is presented in (Table 1).

TABLE 1. Stratigraphic succession in the study area.

\begin{tabular}{|c|c|c|c|c|c|}
\hline \multicolumn{3}{|c|}{ Age } & Formation & Generalized lithologic description & Thickness \\
\hline \multirow{3}{*}{ ن } & \multirow{3}{*}{ 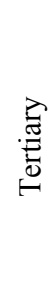 } & \multirow{2}{*}{ 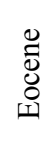 } & Dammam & Limestone, dolomite, marl and shale. & $38 \mathrm{~m}$ \\
\hline & & & Rus & $\begin{array}{l}\text { Marl, chalky limestone and gypsum. } \\
\text { Dominantly anhydrite in subsurface. }\end{array}$ & $56 \mathrm{~m}$ \\
\hline & & 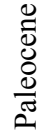 & $\begin{array}{l}\text { Umm-Er- } \\
\text { Radhuma } \\
\text { (UER) }\end{array}$ & $\begin{array}{l}\text { Limestone, dolomitic limestone and } \\
\text { dolomite. }\end{array}$ & $243 \mathrm{~m}$ \\
\hline 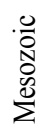 & & & Aruma & $\begin{array}{l}\text { Limestone: subordinate dolomite and shale. } \\
\text { Lower part grades to sandstone in north- } \\
\text { western and southern areas of outcrop. }\end{array}$ & $142 \mathrm{~m}$ \\
\hline
\end{tabular}

The UER aquifer is a single thick hydraulic unit and is water bearing throughout much of the eastern region. Sufficient data is available to develop a reasonably accurate picture of the hydrogeological condition. The thickness of the formation is $240 \mathrm{~m}$, but it increases east and south to $435 \mathrm{~m}$. Within the 
aquifer, the groundwater mainly moves through secondary porosity, and intergranular permeability is expected to be imprecise (Sharaf, 2001). The groundwater flow in the study area is illustrated in (Fig. 2). A reasonably consistent set of flow conditions can be noted by comparing the flow directions indicated by arrows is mainly eastward down the regional dip, but detailed examination of the data in the study area shows how the pattern of flow is probably controlled by geological structures. For example, the tendency for groundwater to move in northeastern direction is probably related to north-south regional fold (see Fig. 1). Groundwater occurs under semi-confined to confined conditions. The average transmissivity values of $7 \times 10^{-5}$ to $0.62 \mathrm{~m}^{2} \mathrm{~s}^{-1}$ while the average storativity of the aquifer is in the range of $10^{-5}$ and $10^{-3}$. The recharge of the aquifer depends on direct infiltration of seasonal rainfall and by infiltration of runoff from wadis; as is the case in other aquifers in Saudi Arabia. The average annual rainfall is $>100 \mathrm{~mm}$. The recharge is very limited, and is estimated that 4 to 8 $\mathrm{mm}$ infiltrate into the aquifer (BRGM, 1979). The age of the groundwater has been determined to be 22,000 years (Al-Bassam, 1987).

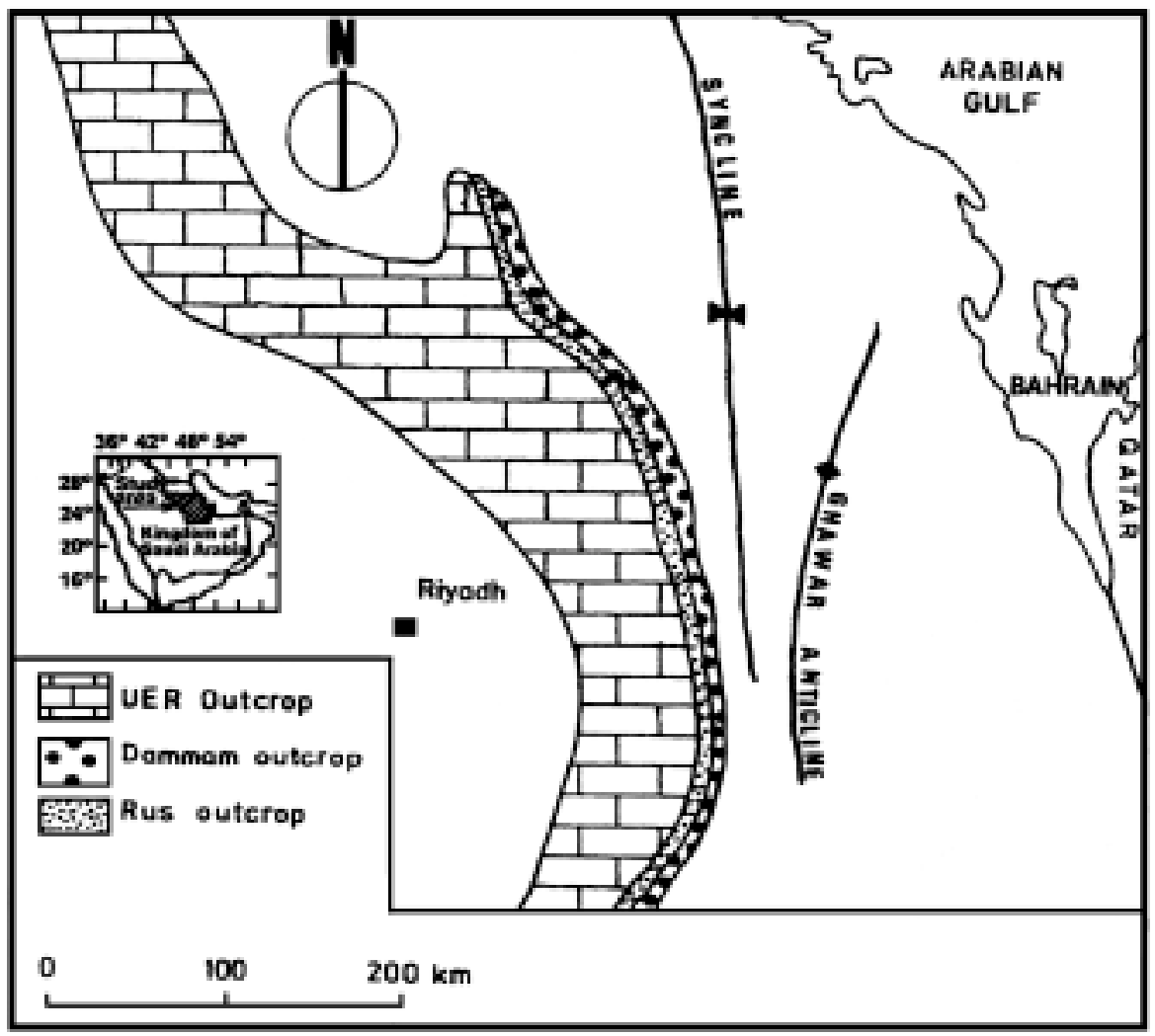

FIG. 1. Location and general geology map. 


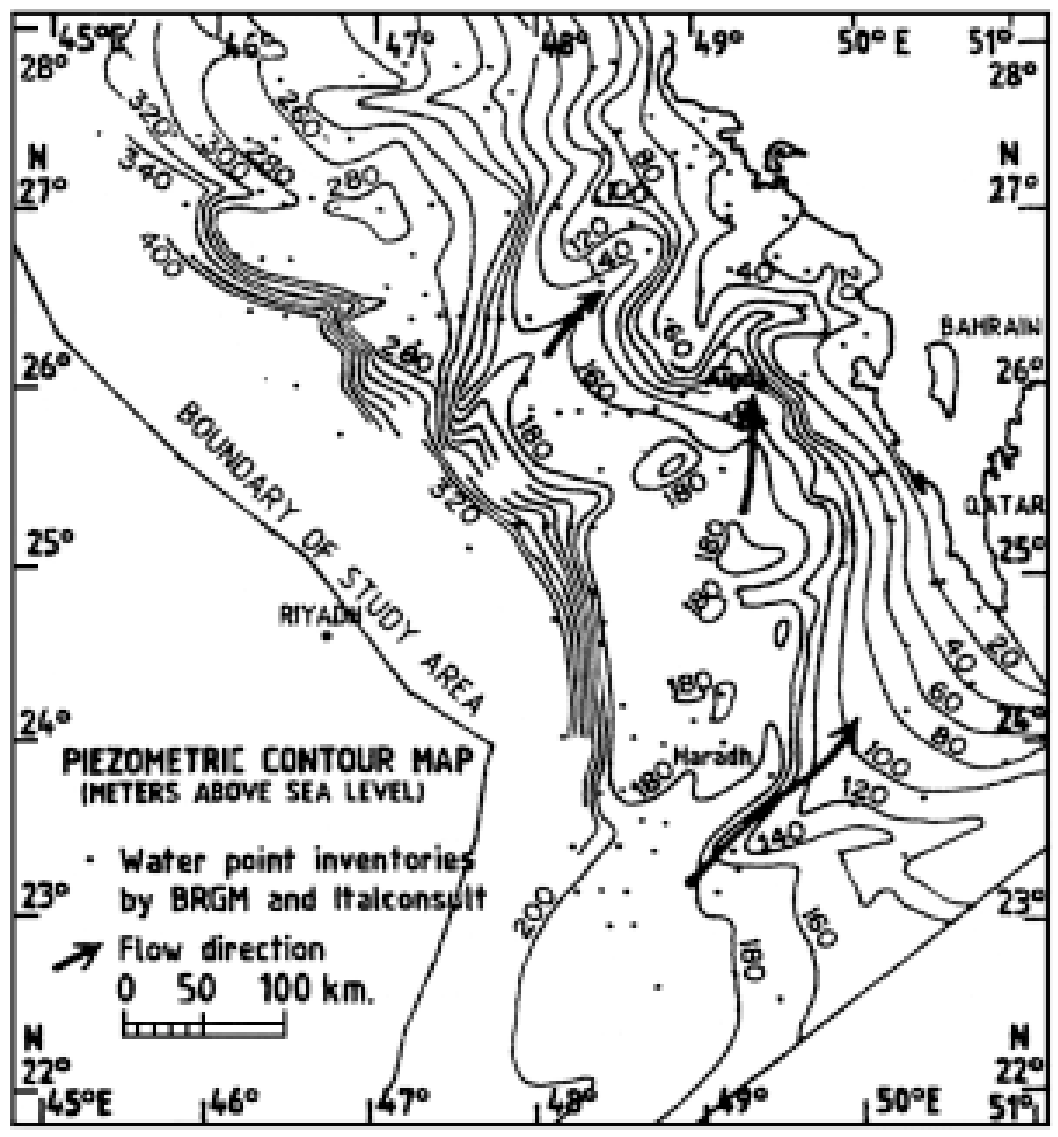

FIG. 2. Piezometric surface distribution map.

\section{Result and Discussion}

Nearly 156 groundwater samples from UER aquifer were analyzed for major ions (e.g. $\mathrm{Na}^{+}, \mathrm{K}^{+}, \mathrm{Ca}^{2+}, \mathrm{Mg}^{2+}, \mathrm{Cl}^{-}, \mathrm{HCO}_{3}^{-}$and $\mathrm{SO}_{4}^{2-}$ ). Standard method (APH/ AWWA/WPCF, 1989) was used. To obtain a better understanding of the groundwater behaviour in contact with different geological formations, the saturation indices of calcite, dolomite and gypsum minerals were calculated, using the hydrochemical program called "Phreeqc" (2001). In addition, 40 groundwater and 8 rainwater samples collected from the recharging zone of the aquifer were taken for stable isotopes analysis. The chemical composition of the groundwater from Dammam aquifer provided by Hassan (1998) was used for comparison purposes. Unfortunately, the saturation indices of the above mentioned minerals of the groundwater from the Dammam aquifer have not been calculated due to the absence of $\mathrm{pH}$ and groundwater temperature in the chemical analyses provided by the author. Ranges and mean of the major constituents are summarized in (Table 2). 
TABLE 2. Ranges and mean of the major ions in UER and Dammam aquifers in mg/l.

\begin{tabular}{|l|c|c|c|c|c|c|}
\hline \multirow{2}{*}{ Ion } & \multicolumn{3}{c|}{$\begin{array}{c}\text { Umm Er Radhuma } \\
(156)\end{array}$} & \multicolumn{3}{c|}{ Dammam** } \\
& Min & Max & Mean & Min & Max & Mean \\
\hline $\mathrm{Ca}^{2+}$ & 35.0 & 1440.0 & 229.0 & 20.0 & 631.0 & 205.0 \\
\hline $\mathrm{Mg}^{2+}$ & 7.0 & 456.0 & 83.0 & 4.9 & 281.0 & 79.0 \\
\hline $\mathrm{Na}^{+}$ & 22.0 & 3882.0 & 321.0 & 85.0 & 1754.0 & 474.0 \\
\hline $\mathrm{HCO}_{3}^{-}$ & 6.0 & 390.0 & 171.0 & 49.0 & 403.0 & 181.0 \\
\hline $\mathrm{Cl}^{-}$ & 12.0 & 7891.0 & 597.0 & 28.0 & 3601.0 & 830.0 \\
\hline $\mathrm{K}^{+}$ & 0 & 84 & 16.0 & - & - & - \\
\hline $\mathrm{S}_{4}^{2-}$ & 13.0 & 2700.0 & 583.0 & 226.0 & 2200.0 & 544.0 \\
\hline $\mathrm{SI}_{\text {calcite }}$ & -1.10 & 2.06 & 0.70 & - & - & - \\
\hline $\mathrm{SI}_{\text {dolomite }}$ & -0.06 & 4.74 & 1.17 & - & - & - \\
\hline $\mathrm{SI}_{\text {gypsum }}$ & -2.37 & 0.08 & -0.91 & - & - & - \\
\hline $\mathrm{TDS}^{2}$ & 220 & 15815 & 2057 & - & - & - \\
\hline
\end{tabular}

**After Hassan (1998), ( ) Number of samples, SI (Saturation Index).

The chemical analyses results of the groundwater of UER aquifer are highly variable. They show that cation composition varies between almost exclusively $\mathrm{Ca}^{2+}$ to dominantly $\mathrm{Na}^{+}$and $\mathrm{Ca}^{2+}$ with relatively lesser amount of $\mathrm{K}^{+}$. Among the anions, $\mathrm{Cl}^{-}$and $\mathrm{SO}_{4}^{2-}$ are dominant (Table 2). On the other hand, the groundwater of UER aquifer is supersaturated with respect to calcite and dolomite but with exception of a few samples, the groundwater is undersaturated with respect to gypsum (Table 2). The areal distribution maps of the major ions were constructed and shown in Fig. 3 to 5. Iso-maps for bicarbonate and potassium ions are rather difficult to draw and are not shown here, since neither constituent displayed the pronounced down gradient increase of the other constituents but rather appeared randomly distributed within the area. Figure 3(a) illustrates the areal distribution map of $\mathrm{Ca}^{2+}$ ion. It generally shows that $\mathrm{Ca}^{2+}$ concentrations increase from the outcrop to the coastal area, from less than $50 \mathrm{mg} / 1$ to more than $1500 \mathrm{mg} / \mathrm{l}$, with no systematic variation observed in its concentration followed the groundwater movement pattern (Fig. 2). It rather shows that there are several tongues of $\mathrm{Ca}^{2+}$ contents extending from the south toward north direction. It covers a large area and its concentration varies between 200 to $600 \mathrm{mg} / 1$. However, high contents of $\mathrm{Ca}^{2+}$ are found near the coastal area and reached up to $2000 \mathrm{mg} / \mathrm{l}$. On the other hand, $\mathrm{Mg}^{2+}$ contents (Fig. 3b) are as low as $9 \mathrm{mg} / \mathrm{l}$ at the outcrop area and increases to values ex- 

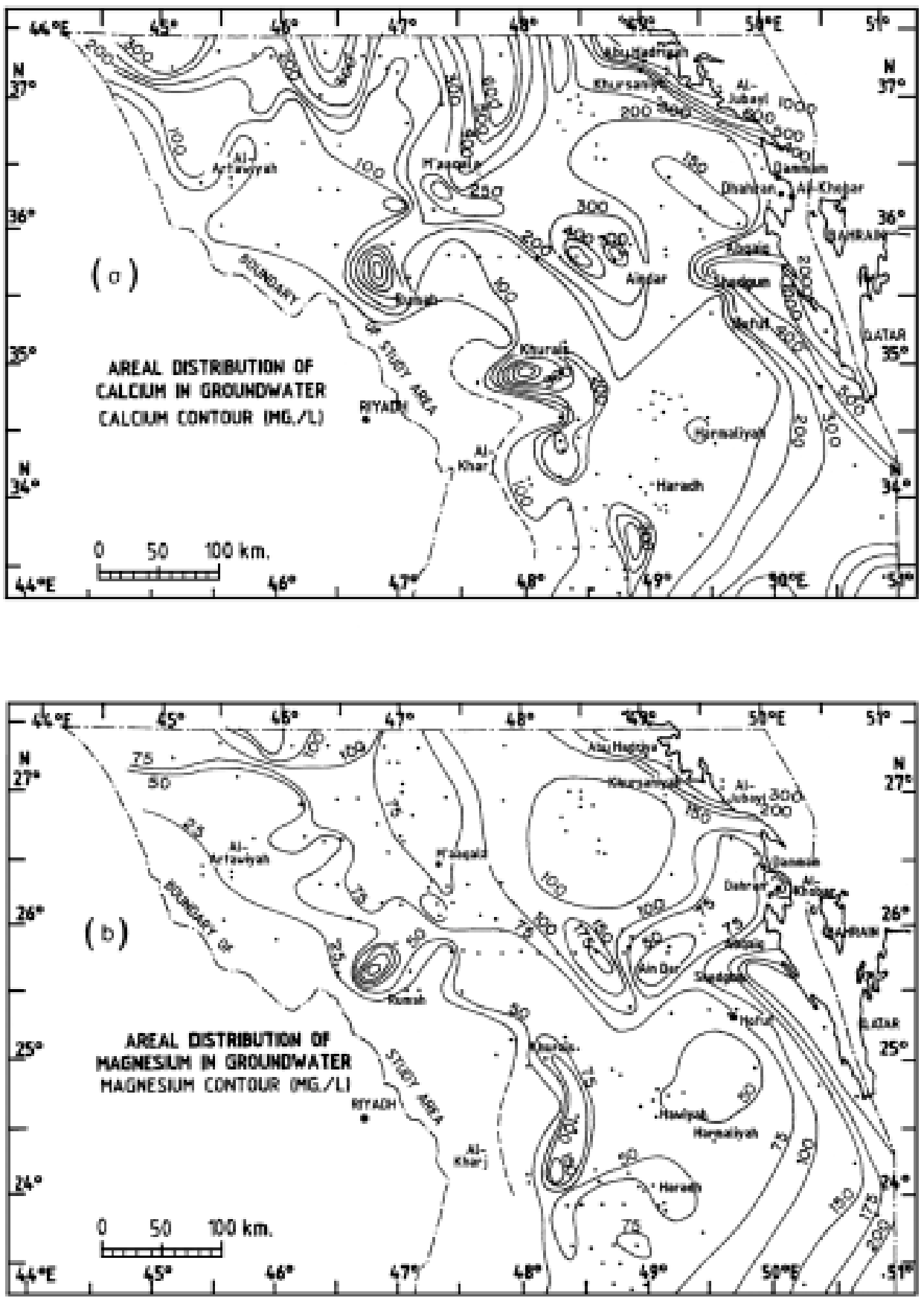

FIg. 3. Areal distribution maps (a) calcium; and (b) magnesium. 
ceeding $300 \mathrm{mg} / \mathrm{l}$ near the coastal region. Generally, $\mathrm{Mg}^{2+}$ distribution is similar to those observed for the $\mathrm{Ca}^{2+}$ concentration. The $\mathrm{Na}^{+}$concentrations (Fig. 4a) increase from less than $25 \mathrm{mg} / \mathrm{l}$ at the outcrop to more than $3800 \mathrm{mg} / \mathrm{l}$ in the coastal area. The distribution map of $\mathrm{Na}^{+}$shows that there is a zone of low $\mathrm{Na}^{+}$ in the central region and extending from the south toward north with maximum $\mathrm{Na}^{+}$contents of less than $400 \mathrm{mg} / \mathrm{l}$. Toward the coastal area and northeast region, the $\mathrm{Na}^{+}$concentrations increased and reached up to $4000 \mathrm{mg} / \mathrm{l}$. The distribution of $\mathrm{Cl}^{-}$contents is shown in Fig. $4 \mathrm{~b}$. The $\mathrm{Cl}^{-}$values range from less than $50 \mathrm{mg} / \mathrm{l}$ at the outcrop to more than $4000 \mathrm{mg} / \mathrm{l}$ near the coastal area. Although, $\mathrm{Cl}^{-}$ion contents usually exceed $\mathrm{Na}^{+}$ion concentrations, the $\mathrm{Cl}^{-}$distribution follows the same pattern as that of $\mathrm{Na}^{+}$. Therefore, the same anomalies discussed for $\mathrm{Na}^{+}$are prominent in the case of $\mathrm{Cl}^{-}$. The areal distribution of $\mathrm{SO}_{4}^{2-}$ ion is shown in Fig. 5. The $\mathrm{SO}_{4}^{2-}$ concentration range between less than $100 \mathrm{mg} / \mathrm{l}$ at the outcrop to more than $2000 \mathrm{mg} / \mathrm{l}$ in the northern central zone and near the coastal area. On the other hand, two areas can be distinguished with respect to $\mathrm{SO}_{4}^{2-}$ concentrations. In the northern half is enriched with $\mathrm{SO}_{4}^{2-}$ as the concentrations rise sharply to exceed $2000 \mathrm{mg} / \mathrm{l}$, whereas in the southern part, the contents remained comparatively low for a considerable distance from the outcrop area. Beyond this distance, the $\mathrm{SO}_{4}^{2-}$ concentration starts increasing to reach a high value of more than $1800 \mathrm{mg} / \mathrm{l}$ in the southeast corner.

On the other hand, data for $\delta \mathrm{D}$ and $\delta^{18} \mathrm{O}$ were reported in the usual delta notation with SMOW as the standard (Graig, 1961). It shows that the $\delta \mathrm{D}$ values range from $-55.4 \%$ to $-2.11 \%$, and $\delta^{18} \mathrm{O}$ values range from $-6.46 \%$ to $-1.18 \%$ o (Table 3). Areal distributions of $\delta \mathrm{D}$ and $\delta^{18} \mathrm{O}$ concentrations are shown in Fig. (6a) and (6b). They generally indicate that both elements are depleted downgradient rather than being enriched. Moreover, in the area to the west to Haradh village further south of the study area and southward, the groundwater isotopic contents display highly negative values, although, this area is characterized by an extremely arid conditions and lack of recharge (Al-Bassam, 1987).

As shown from the distribution maps of major ion contents no systematic variation in the major ion contents appears, and concurrent with groundwater flow direction, but rather several tongues of low concentrations occurred and almost prominent the middle zone and extend away from the outcrop towards the east, south and northeast. On the other hand, the isotopic contents of the groundwater almost show that the groundwater is depleted downgradient, which would not be expected but often being enriched with groundwater travel through its flow-path to east and north directions. Under this condition, it is believed that a strong potential factor may affect the groundwater chemistry in the area.

On the other hand, one important question to be considered is whether flow conditions that exist at present were the same over the last 22,000 years. Then 

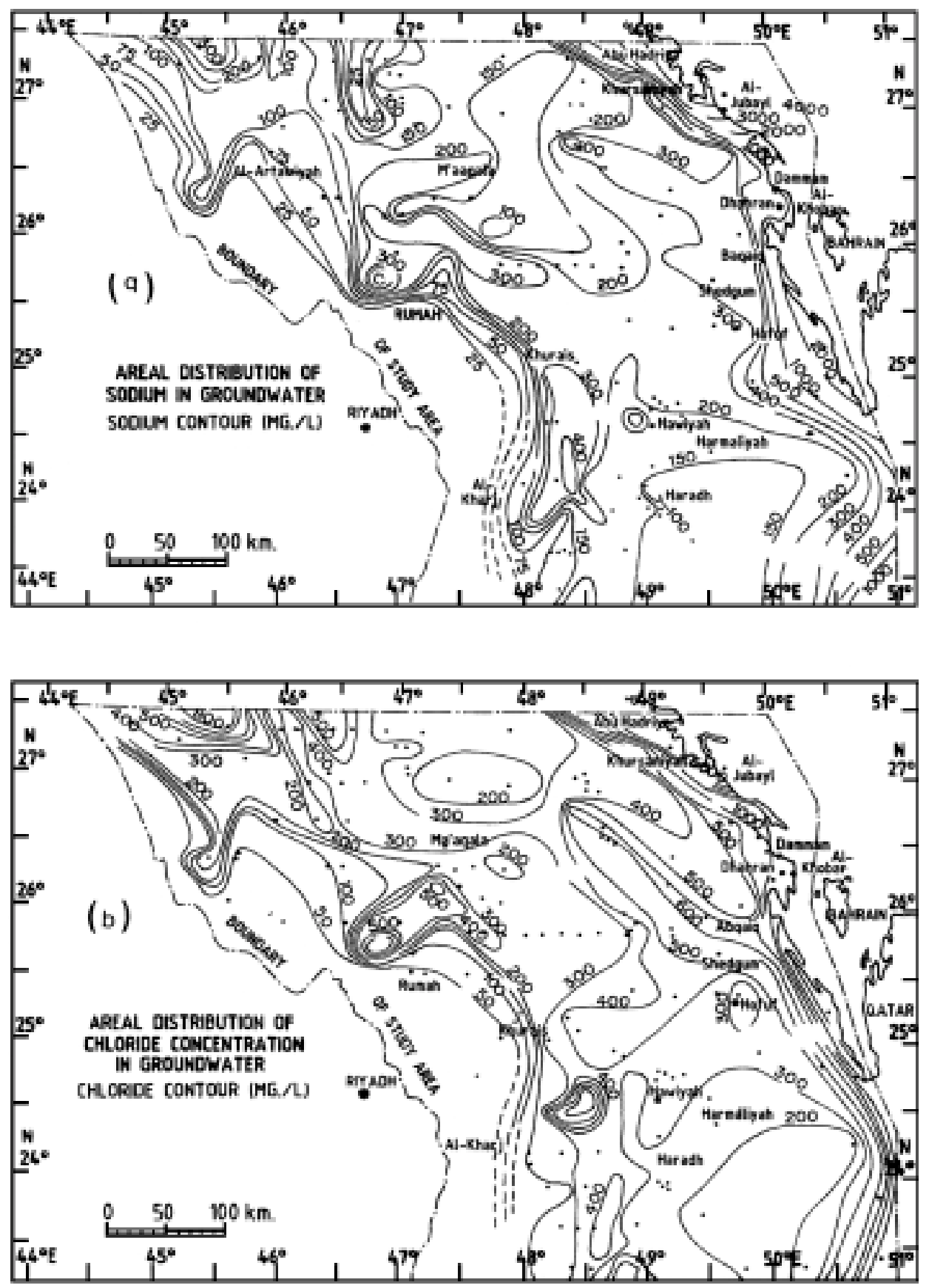

FIG. 4. Areal distribution maps (a) sodium; and (b) chloride. 


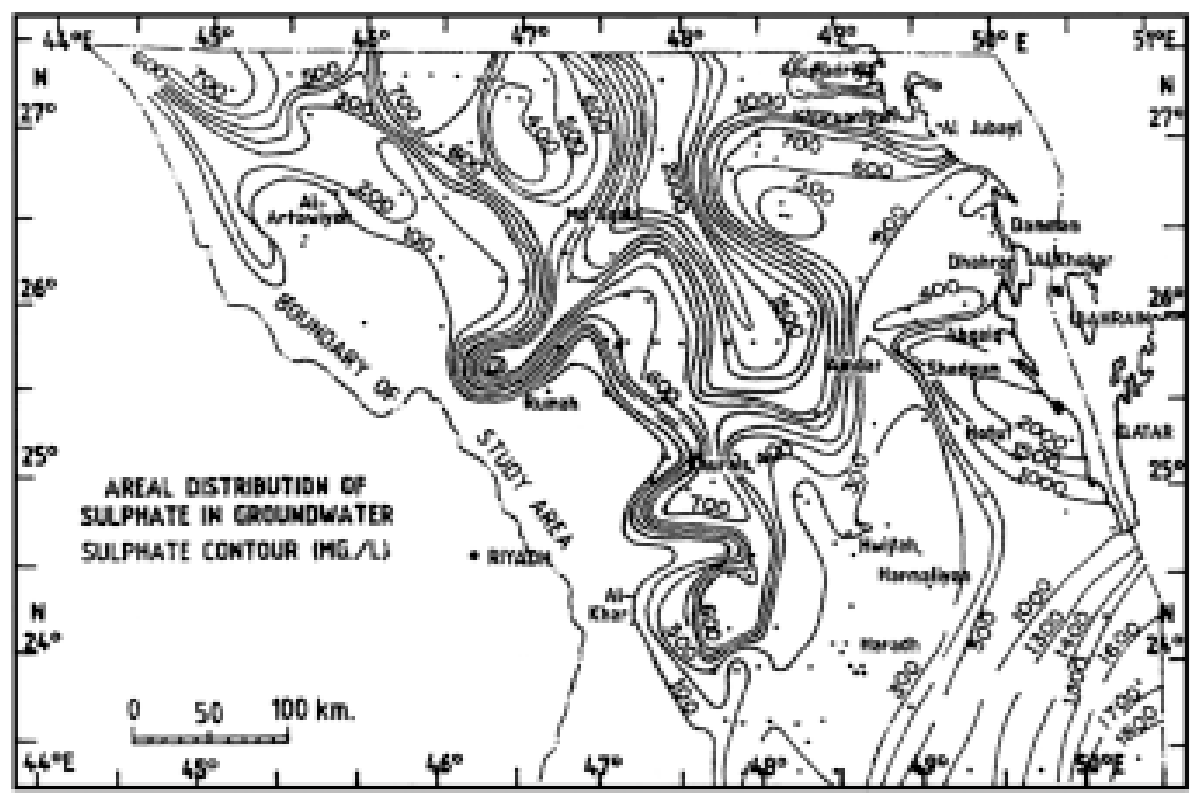

FIG. 5. Areal distribution map of sulphate.

why the groundwater down gradient is more saline and rather depleted in its isotopic composition? As the aquifer system is a relatively permeable and attains an active flow system (Sharaf, 2001), it is difficult to see why the groundwater in UER aquifer has not been completely flushed by low saline recharge water displacing preexisting formation water. On the other hand, the isotopic content of the groundwater is completely different from that found in the modern recharging water (Table 3), which is enriched in heavy isotopes. This may lead to suggest that the UER is probably receiving sufficient contribution of younger (lighter isotopic composition), and a relatively low saline water (Table 2) from the overlying Dammam aquifer through the thickening $56 \mathrm{~m}$ but fractured and fissured anhydrite and gypsum of the Rus Formation (Table 1), and the mixing process might be continuous as a result of leakage. This fact is substantiated by the following evidences which come from the chemical composition of the groundwater of UER aquifer.

The chemical composition of the groundwater of UER aquifer shows that a relatively high contents of $\mathrm{SO}_{4}^{2-}$ ions in the aquifer mainly composed of limestone and dolomite. However, high concentrations of $\mathrm{SO}_{4}^{2-}$ seem to have entered the solution through dissolving anhydrite and gypsum of the Rus Formation due to vertical flow of water from Dammam aquifer. This conclusion could be confirmed by plots of $\mathrm{Ca}^{2+}$ against $\mathrm{HCO}_{3}^{-}, \mathrm{SO}_{4}^{2-}$ and $\mathrm{HCO}_{3}^{-}+\mathrm{SO}_{4}^{2-}$ (Fig. 7). This figure indicated that neither limestone $\left(\mathrm{CaCO}_{3}\right)$ of UER aquifer (Correlation Coefficient $\mathrm{R}^{2}=0.001$ ) nor gypsum $\left(\mathrm{CaSO}_{4} \cdot 2 \mathrm{H}_{2} \mathrm{O}\right)$ and anhydrite 
TABLE 3. Ranges of the isotopic contents of the groundwater of UER aquifer and rainwater.

\begin{tabular}{|cc|c|c|c|c|c|c|}
\hline \multirow{2}{*}{ Element } & \multicolumn{3}{|c|}{$\begin{array}{c}\text { Umm Er Radhuma } \\
\text { (40) }\end{array}$} & \multicolumn{3}{c|}{ Rainfall } \\
\hline & & Min & Max & Mean & Min & Max & Mean \\
\hline$\rho^{18} \mathrm{O}$ & $(\%)$ & -6.46 & -1.18 & -3.52 & 1.72 & 4.52 & 1.21 \\
\hline$\Delta \mathrm{D} \quad(\%)$ & -55.4 & -2.11 & -24.43 & -11.2 & 28.3 & 14.3 \\
\hline
\end{tabular}

( ) Number of samples.

$\left(\mathrm{CaSO}_{4}\right)\left(\mathrm{R}^{2}=0.75\right)$ of the Rus Formation are by themselves control $\mathrm{Ca}^{2+}$ concentrations, but together the carbonate and sulfate minerals dissolution do balance the concentration trend of $\mathrm{Ca}^{2+}$ in the groundwater of UER aquifer $\left(\mathrm{R}^{2}=0.84\right)$. Another possible indication of leakage phenomena from the overlying aquifer can be depicted from Durov's diagram (Fig. 8). This diagram indicates that most of groundwater samples plotted along the mixing and dissolution line, suggesting that mixing processes between low mineralized water (Dammam aquifer) with a relatively high saline water (UER aquifer). Figure 9, on the other hand, illustrated the relationship between $\mathrm{Cl}^{-}$and $\delta^{18} \mathrm{O}$. It reflects that two groups can be distinguished. Group I contains 26 wells. This group has a relatively homogeneous chemical and isotopic composition. This group is probably affected by the groundwater leaked from the upper aquifer. Group II has a higher $\mathrm{Cl}$ concentration. This group might reflect the original chemical and isotopic compositions of the groundwater of UER aquifer. However, such variation in $\mathrm{Cl}^{-}$and $\delta^{18} \mathrm{O}$ contents observed may indicate that stratification in the groundwater chemistry exist. This conclusion might be supported by the previous investigation carried out by Al-Bassam (1987). He outlined that the groundwater salinity increased with depth, and $\mathrm{Na}^{+}$and $\mathrm{Cl}^{-}$ions contents are increased. Whereas, $\mathrm{Ca}^{2+}, \mathrm{Mg}^{2+}$ and $\mathrm{SO}_{4}^{2-}$ being decreased. His study might be considered as an indication confirmed the earlier conclusion that the UER aquifer has received sufficient contribution of younger (lighter isotopic composition), and a relatively low saline water enriched in $\mathrm{Ca}^{2+}$ and $\mathrm{SO}_{4}^{2-}$ contents from Dammam aquifer through the Rus Formation and being mixed with relatively high saline water of UER aquifer.

On the other hand, upward leakage from Aruma to the UER aquifer can be ruled out, because it does not agree with the hydrogeological data where the piezometric level of Aruma is lower than the UER piezometric level which suggests a downward leakage from the UER to Aruma aquifer.

It appears that leakage process probably operated for a long time, the flushing is incomplete and the zones of mixing, besides, the geochemical evolution processes between the groundwater and the aquifer materials still remain. More- 

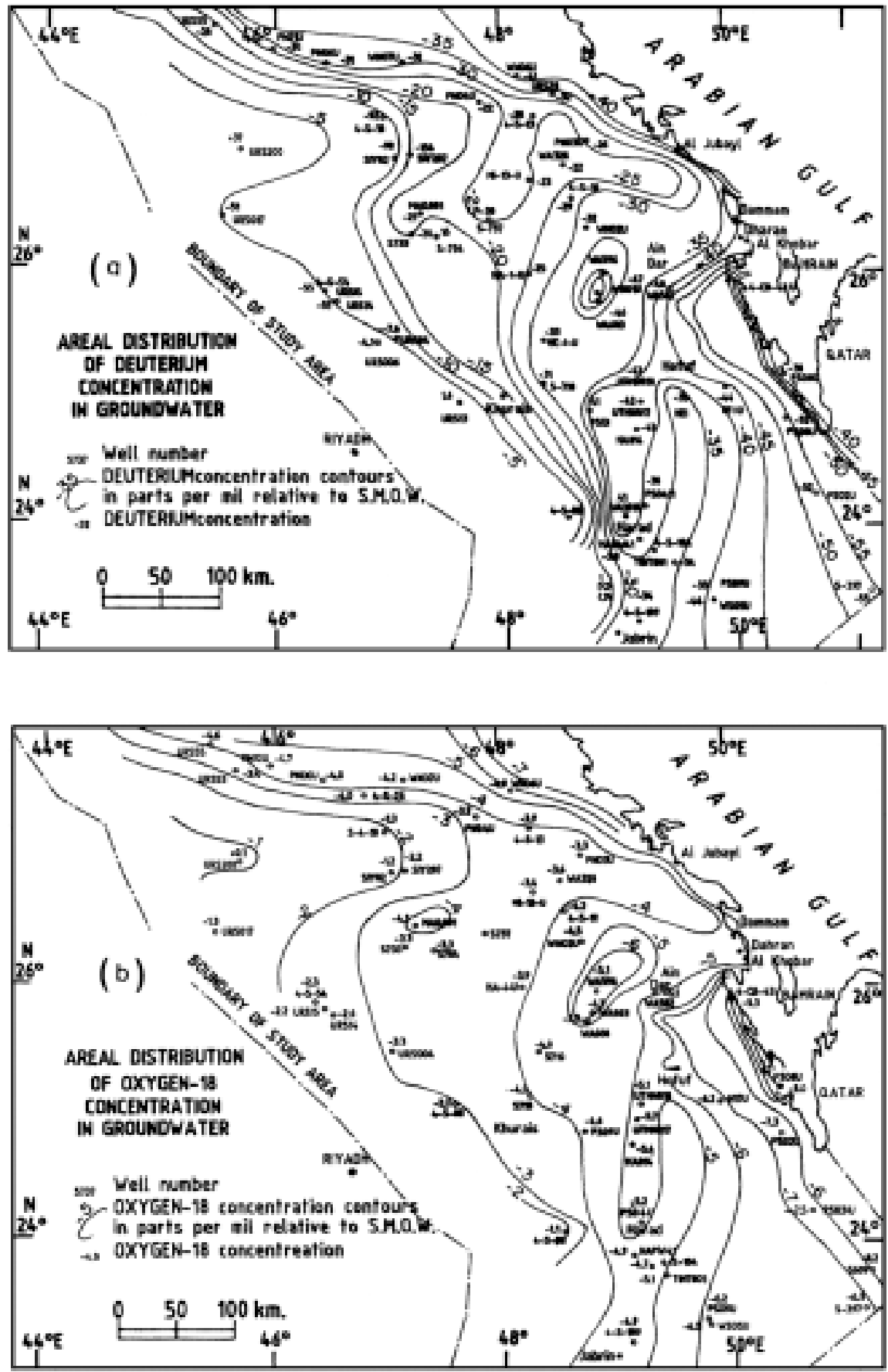

FIG. 6. Areal distribution maps; (a) $\delta \mathrm{D}$, (b) $\delta^{18} \mathrm{O}$ (parts per mil relative to SMOW). 

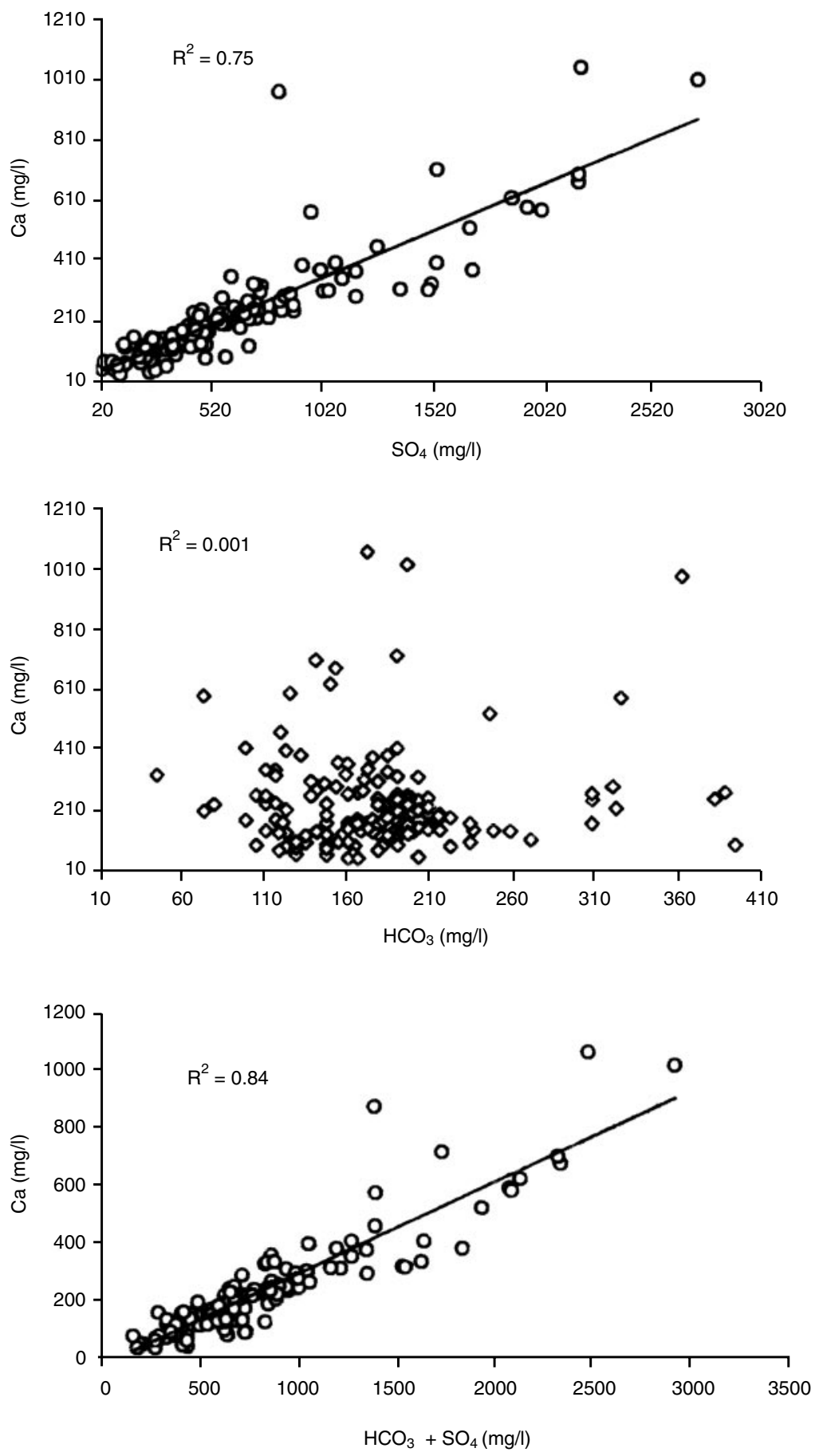

Fig. 7. Relationship of $\mathrm{Ca}^{2+}$ with $\mathrm{HCO}_{3}^{-}, \mathrm{SO}_{4}^{2-}, \mathrm{HCO}_{3}^{-}+\mathrm{SO}_{4}^{2-}$. 


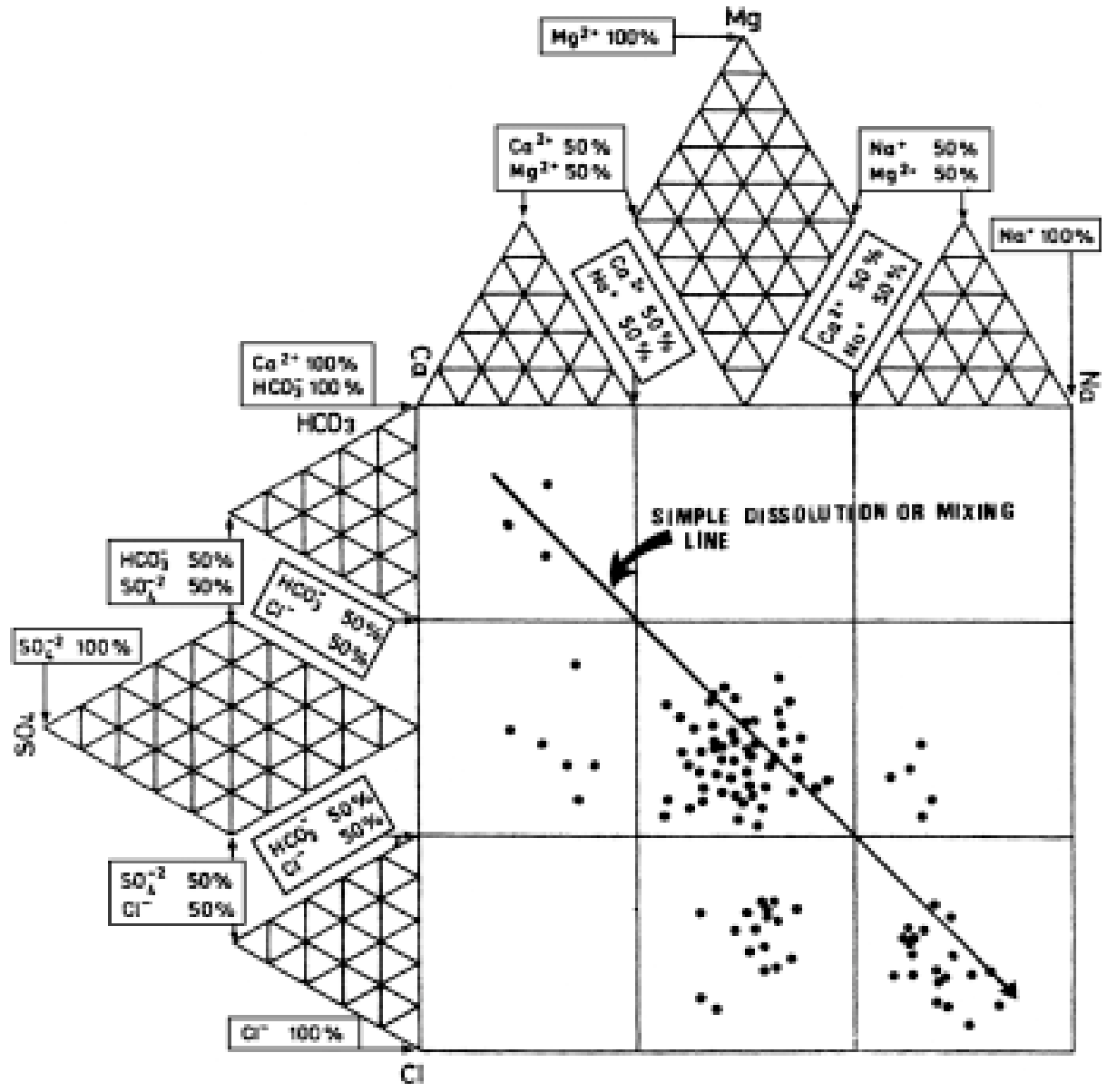

FIG. 8. Plotting of groundwater samples in Durov's diagram. 


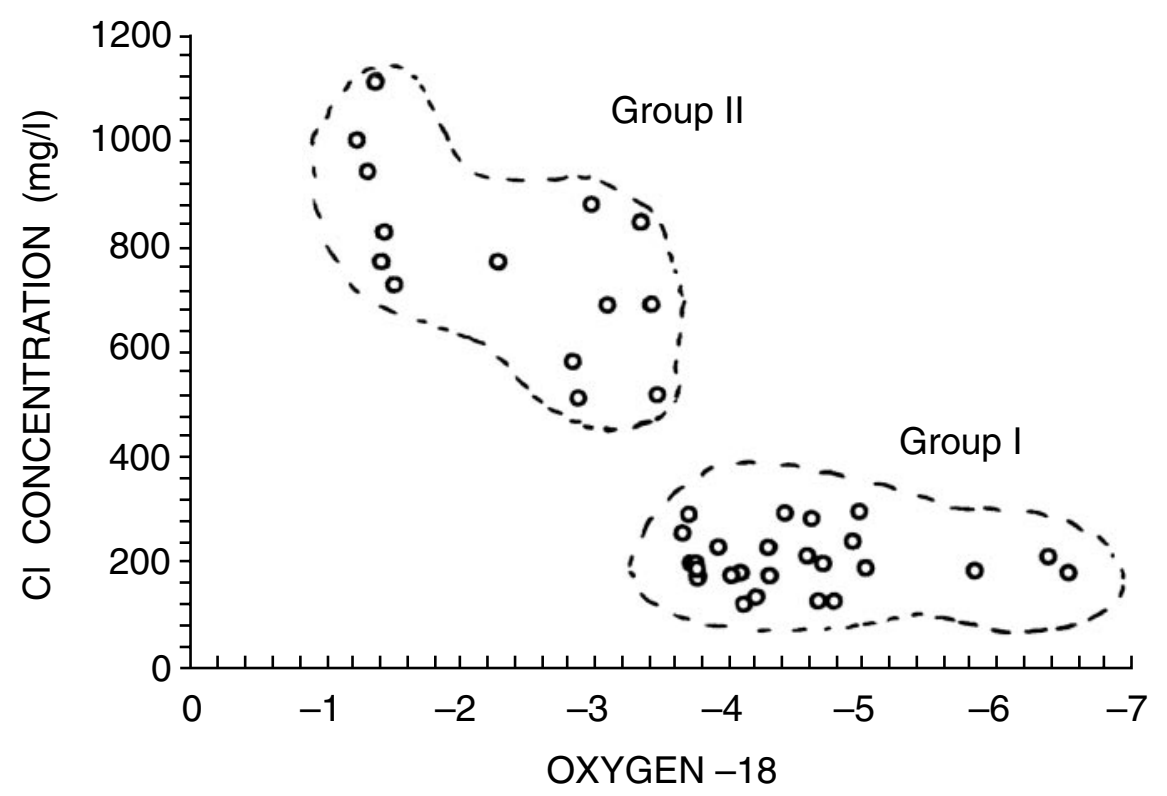

FIG. 9. Relationship between $\mathrm{Cl}$ and $\delta^{18} \mathrm{O}$.

over, the effect of vertical downward leakage may continue significantly as a consequence of the decline in the water levels in UER aquifer since the aquifer is being extensively developed for agricultural projects as well as for major domestic supplies in the area.

\section{Conclusion}

The groundwater in the UER aquifer is controlled by mixing processes due to downward leakage of younger water from the Dammam aquifer depleted in heavy isotopes and low in TDS. This fact is supported by the chemical and isotopical compositions of the groundwater. Furthermore, the water chemistry of the UER aquifer is also controlled by chemical reactions between water and the aquifer itself.

\section{References}

Al-Bassam, A.M. (1983) A Quantitative Study of Harad Wellfield, Umm-ER-Radhuma Aquifer, M.Sc. Thesis, Ohio University, U.S.A.

Al-Bassam, A.M. (1987) Hydrochemical Computer Modeling in Groundwater Related Problem, Ph.D. Thesis, Univ. of Birmingham, U.K.

Al-Sayari, S. and Zotl, J. (1978) Quaternary Period in Saudi Arabia, Springer-Verlag, Wien, New York, 334 p.

APH/AWWA/WPCF (1989) Standard Methods for the Examination of Water Wastewater, Washington, DC, American Public Health Association. 
BRGM (1976) Hydrogeological Investigations of the Al Wasia Aquifer in the Eastern Province of Saudi Arabia, Unpub. Report, Ministry of the Agriculture and Water, Kingdom of Saudi Arabia.

BRGM (1979) New Data on Groundwater Resources of AlKharj Area, Unpub. Report, Ministry of Agriculture and Water, Kingdom of Saudi Arabia.

Craig, H. (1961) Isotopic variations in meteoric waters, Science, 133: 1702-1703.

Groundwater Development Consultant Company (GDC) (1979) Final Draft of Umm-ErRadhuma Study, Unpub. Report, Ministry of Agriculture and Water, Kingdom of Saudi Arabia .

Hassan, M.H. (1998) Major ion distributions in Khober aquifer, Eastern Saudi Arabia, Arabian Jourl. for Sci. and Eng., Water Reso. In Arabian Peninsula, Part II, 23, (1C): 69-88.

Italoconsult (1969) Water and Agricultural Development Studies for Area IV, Kingdom of Saudi Arabia, Unpub. Report, Ministry of Agriculture and Water, Kingdom of Saudi Arabia.

Phreeqc Interactive Alpha (2001) US Geological Survey, V. 2.4.2, Denver, USA.

Sharaf, M.A. (2001) Review of the Hydrogeological and Hydrochemical Aspects of Groundwater in the Umm Er Radhuma Aquifer System, Arabian Peninsula, J. of African Earth Sci., 33(2): 349-362.

Sogreah (1968) Water and Agricultural Development Studies, Area V, Final Report, Ministry of Agriculture and Water, Kingdom of Saudi Arabia.

Watuki, G.M.G.H. (1968) Preliminary Study of Umm-Er-Radhuma Aquifer, Unpub. Report, Ministry of Agriculture and Water, Kingdom of Saudi Arabia.

Watuki, G.M.G.H. (1971) Final Report on Water and Wells, Faisal settlement project, Haradh. Unpub. Report, Ministry of Agriculture and Water, Kingdom of Saudi Arabia. 


\title{
استخدام التركيب الكيميائي والنظائر البيئية لدراسة احتمال التسرب

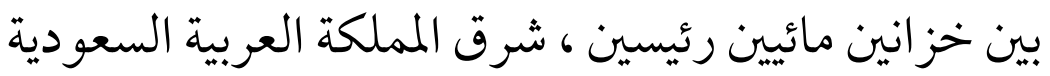

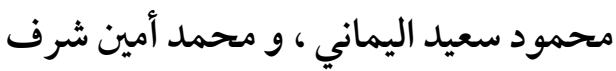

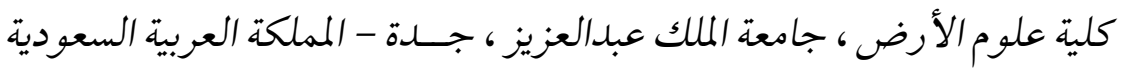

المستخلص . تحاليل العناصر الرئيسية لـ 107 عينة مياه جوفية متمعدنة

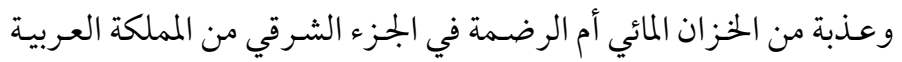

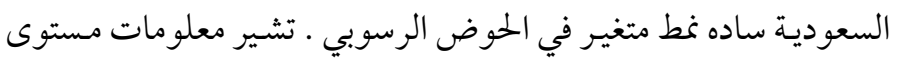

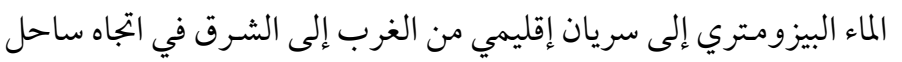

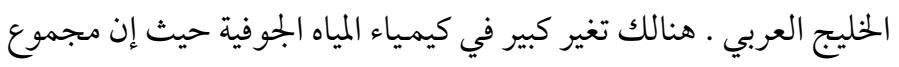

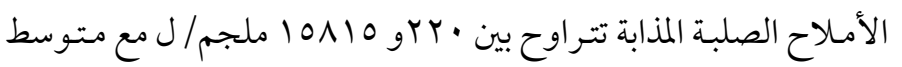

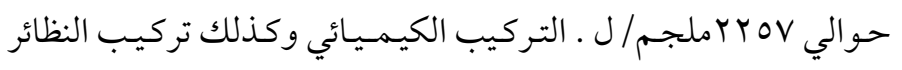

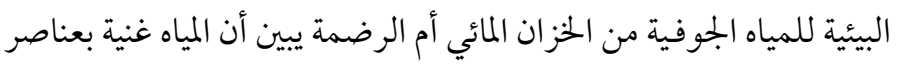

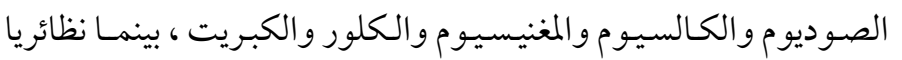

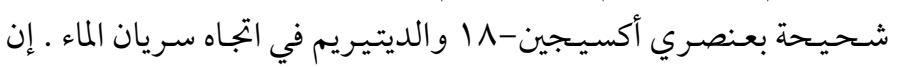

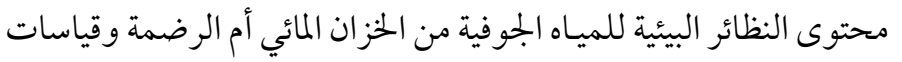

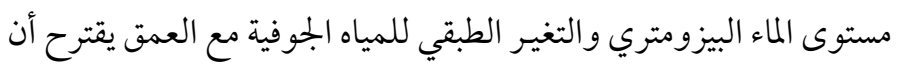

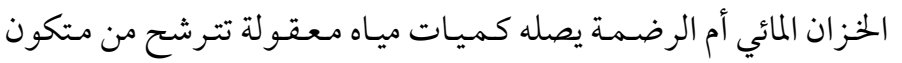

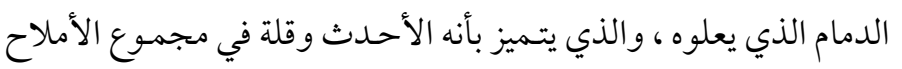

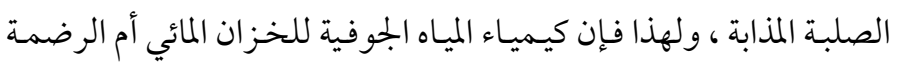

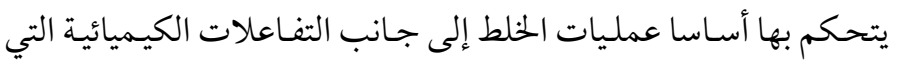

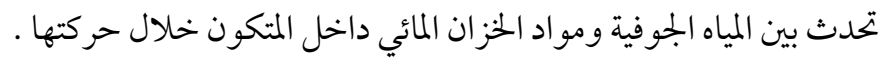

